\title{
A BRIEF INTRODUCTION TO MEDICAL MISADVENTURE
}

\section{Petra Butler}

This article examines the development of medical misadventure law in New Zealand. It discusses the various pieces of legislation impacting on the definition of "medical misadventure" as well as considering the punitive damages cases that are emerging outside ACC against allegedly negligent health professionals and organisations. The author states that the difficulty in devising an appropriate system of accountability lies in the special trust of the doctor-patient relationship.

There are certain things that civilised society simply cannot permit to be done to its members, even if they are compensated for their resulting losses. ${ }^{1}$

Today's expectations in regard to medical treatment are high. Miracle drugs, elaborate surgical procedures which no-one would have dreamed of 50 years ago, genetically manufactured drugs and the first steps in genome therapy seem to make nearly everything achievable today. Within a large proportion of the population one finds an unshakeable belief in medicine. ${ }^{2}$ However, that faith can sometimes be shaken when the desired result is not achieved.

The doctor-patient relationship is a special one which can have a wide variety of variables. As Peter Roberts' paper points out healthcare is not "just part of a linear production process" but rather health care is of a "stochastic nature". ${ }^{3}$ However, one thing is certain: the doctor-patient relationship is one of immense trust from the side of the patient. The medical professional who is initially a complete stranger, over a period of time becomes the confidant knowing often the most intimate details about a person. And the act or omission of the medical professional always impacts

* $\quad$ Senior Lecturer, Victoria University of Wellington; LLM(VUW); PhD (Goettingen).

1 Supreme Court of India "Settlement Order 14/15.02.1989 (4 May 1989)" in Madhara Menon (ed) Documents and Court Opinions on Bhopal Gas Leak Disaster Case (National Law School of India University, Bangalore, 1991) 296.

2 Peter Roberts "Policy to Protection: The Role of Human Nature and System Nature in Preventing Patient Injury" (2004) 35 VUWLR 829 notes that in the last 25 years the doctor-patient relationship has changed and that especially trust in the competence, altruism and integrity of doctors has slipped.

3 Roberts, above n 2, 839. 
on the mental or physical health of the patient. A mistake by a medical professional, therefore, nearly always has negative consequences for the patient either because the patient's problem does not get better or because the problem gets even worse. Because of the consequences of acts or omissions of a medical professional and the immense trust involved in the doctor-patient relationship, the legal sphere of this relationship has from, early on, been subject to attention.

The failure to cure a patient was already a subject in the Hammurabian Code $^{4}$ and in De Lege Hippocrates bemoaned the deficient avengement of medical mistakes by Greek courts. ${ }^{5}$ Caius Plinius Secundus reprehended their inadequate punishment in his Historia Naturalis in the same way. ${ }^{6}$ The Constitutio Criminalis Carolina relied on terms like intention, carelessness, knowledge, thoughtless and unmethodical acts, and unscientific therapy to establish whether an unfavourable outcome for the patient, especially death, was punishable according to its article $134 .^{7}$

Even though the risks of medical acts and omissions were recognised early on and were the subject of criminal offences, the medical profession has been held in high esteem over the centuries. Even today the general practitioner is often consulted by their patient not only as medical advisor but also as advisor on all life problems.

Civil or criminal cases against medical professionals used to be rare. The American Medical Association published statistics in the 1960s according to which only 19 per cent of all medical professionals would be subject to a law suit in regard to a potential professional mistake made. ${ }^{8}$

While the medical profession in the 1960s was nearly "untouchable", the picture changed in the 1970s. The United States experienced a dramatic rise in civil law suits against the medical profession, leading commentators to speak of a medical malpractice crisis. ${ }^{9}$ A case study, sponsored by the National Association of Insurance Commissioners, found that between 1975 and 1978 every year 3.83 civil law suits were filed per 100 practicing medical professionals. And, 1.45

4 Hammurabian Code Art 218 (Babylon 1728 to 1686 BC) translated by LW King $<$ http://www.lawresearch.com> (last accessed 15 July 2004).

5 Hippocrates (460 to 377 BC) cited according to Hans Joachim Mallach, Gerhard Schlenker, and Alfons Weiser, Aerztlicher Kunstfehler (Fischer, Stuttgart, 1993) 2.

6 Cajus Plinius Secundus (23 to 79 AD) Historia Naturalis, book 29.

7 Peinliche Halsgerichtsordnung Kaiser Karl V Constitutio Criminalis Carolina (Reichstag zu Regensburg, 1532).

8 Robert Dingwell, Paul Fenn and Lois Quam Medical Negligence-A Review and Bibliography (Centre for Socio-Legal Studies, Oxford, 1991) 4.

9 Paul Weiler Medical Malpractice on Trial (Harvard University Press, Cambridge (Mass), 1991) 2 and following; Randall Bovbjerg and Thomas Metzloff "Foreword" in Medical Malpractice: Lessons for Reform (1991) 54 L \& Contemp Probs 1; Glen Robinson "The Medical Malpractice Crisis of the 1970s: A Retrospective" in Medical Malpractice: Can the Private Sector find Relief? (1986) 49 L \& Contemp Probs 5,5 . 
law suits would lead to a compensation payment to the patient. ${ }^{10}$ The United States experienced a second peak in regard to civil law suits against medical professionals in the mid-1980s. ${ }^{11}$ Even if it is estimated that the frequency of civil law suits is falling or at least remains stable, ${ }^{12}$ the costs arising out of the remaining claims has risen steadily. ${ }^{13}$ A study published in April 2004 by the United States Department of Justice showed that the overall win rate for medical malpractice plaintiffs was about half of that found among plaintiffs in all tort trials. However, the median award in medical malpractice trials was nearly 16 times greater than the overall median award in all tort trials. Plaintiff winners were awarded $\$ 1$ million or more in approximately a third of medical malpractice trials (punitive damages remained rare in medical malpractice trials). ${ }^{14}$

In Great Britain, as well, the number of medical malpractice claims has risen steadily. Between 1983 and 1987 alone, for example, the claims for medical malpractice doubled and the amount of damages awards rose significantly. ${ }^{15}$

Different solutions have been suggested and developed in the academic literature and by governments within the United States, Canada and Great Britain to combat the so-called medical malpractice crisis. ${ }^{16}$ Solutions have included the idea of addressing medical liability in the doctor-

10 Dingwall, Fenn and Quam, above n 8, 4.

11 Paul Weiler "The Case for No-Fault Medical Liability" (1993) 52 Maryland L Rev 908, 908-909; Bovbjerg and Metzloff, above $\mathrm{n} 9$.

12 Thomas Cohen, United States Department of Justice "Medical Malpractice Trials and Verdicts in Large Counties 2001" (NCJ 203098) <http//www.ojp.usdoj.gov> (last accessed 1 October 2004). The data was collected from the 75 most populous counties in the United States during 2001. It found that 1156 medical malpractice trials were litigated during that year of which 96 per cent were disposed of by jury trial. In an estimated nine out of ten medical malpractice trials, the alleged harm involved either permanent injury or a death claim.

13 Michael Jones Medical Negligence (Sweet \& Maxwell, London, 1991) 1.05; Dingwall, Fenn and Quam, above n 8, 8-10.

14 Cohen, above n 12.

15 Michael Jones " Defective Services: A New Dimension for Medical Malpractice? " in BS Jackson and D McGoldnick (eds) Legal Visions of the New Europe: Essays Celebrating the Centenary of the Faculty of Law University of Liverpool (Martinus Nijhoff Publishers, London, 1993) 311, 1.05; Dingwall Fenn and Quam, above n 8, 8.

16 See for a detailed reference: Report of the Royal Commission on Civil Liability and Compensation for Personal Injury (1978) Cmnd 7054; Robert Prichard Compensation for Personal Injury and Professional Indemnity in Health Care: A Discussion Paper (Department of Health, Toronto, 1990). The solution depends on the philosophical attitude of the author: "[t]he distinction between an individualistic political philosophy and a more socialist philosophy affects the choice of compensation systems in many ways. Socialists tend to favour active state participation in the provision of help and care to those in need, whereas individualists often advocate that the state should just provide a coercive mechanism for enabling injured persons to obtain compensation from their injurers if they choose to. Individualists often favour providing 
patient contract. ${ }^{17}$ This possibility, however, has been rejected by the academic literature and the judiciary because of the lack of equal bargaining power between doctor and patient. ${ }^{18}$ Another suggested way of combating the medical malpractice crisis is widening the disciplinary system, including the establishment of a medical practitioners' index, and an emphasis in evaluation of risk management. The index would enable employers, especially hospitals, to access information about prospective medical doctor employees and more particularly their previous involvement in civil and criminal litigation. ${ }^{19}$ Some States in the United States have tried to cap the influx of medical malpractice claims by curtailing access to the courts. ${ }^{20}$ This has been done by, for example, increasing lawyers' fees for medical malpractice cases, shortening limitation periods, ${ }^{21}$ providing for mandatory mediation, screening panels (these panels consist typically of doctors and lawyers who assess the cases in regard to their likely success in court) influencing whether a patient should take the claim to court or not, ${ }^{22}$ changing the burden of proof and damages caps. ${ }^{23}$

However, despite all these efforts to minimise the medical malpractice crisis the debate about how best to deal with a soured doctor-patient relationship is still as much debated today as it was ten or twenty years ago. This Symposium and its session dedicated to the problems faced if a medical misadventure case occurs, is a good example. ${ }^{24}$

It is especially interesting to discuss medical misadventure arising out of the doctor-patient relationship in New Zealand since New Zealand has been spared the medical malpractice crisis due to the coming into force of the accident compensation scheme in 1972. The low number of reported

assistance in cash, which the recipient can then use as they choose, rather than assistance in kind." Peter Cane Atiyah's Accidents, Compensation and the Law (4 ed, Fred B Rothman \& Co, London, 1987) 9.

17 Clark Havinghurst "Private Reform of Tort-Law Dogma: Market Opportunities and Legal Obstacles" (1986) 49 L \& Contemp Probs 143; Richard Epstein "Contracting out Medical Malpractice Crisis" (1977) 20 Perspectives in Biology and Medicine 228. See also the discussion of these possibilities in light of the Harvard Study: Weiler, above n 9, 93.

18 Tunkl $v$ Regents of University of California (1963) 60 Cal 2d 92; Dingwall, Fenn and Quam, above n 8, 58 and 59 .

19 Orley Lindgren, Ronald Christensen and Don Mills "Medical Malpractice Risk Management Early Warning Systems" (1991) 54 L \& Contemp Probs 23; Laura Marlock and Faye Malitz "Do Hospital Risk Management Programs Make a Difference?: Relationships between Risk Management Program Activities and Hospital Malpractice Claims Experience" (1991) 54 L \& Contemp Probs 1.

20 Weiler, above n 9, 27.

21 Weiler, above n 9, 28 n 33 and 34

22 Weiler, above $\mathrm{n} 9,29 \mathrm{n} 42$ and 43.

23 Dingwall, Fenn and Quam, above n 8, 68 and following.

24 See Roberts, above n 2; Bronwyn Howell "Medical Misadventure and Accident Compensation in New Zealand" (2004) 35 VUWLR 857. 
medical malpractice cases before the coming into force of the scheme means that a medical malpractice crisis was not the reason for developing the scheme. ${ }^{25}$ The New Zealand accident compensation scheme has been heralded by some as an excellent example of how to combat the medical malpractice crisis. ${ }^{26}$ However, the case law in regard to medical misadventure under the accident compensation scheme and the legislative activity in regard to medical misadventure shows that even this heralded solution is not without problems.

In the original 1972 Act, medical misadventure was not mentioned. However, already by the 1974 amendments to the Accident Compensation Act 1972 personal injury by accident was defined to include "medical, surgical, dental, or first aid misadventure". ${ }^{27}$ The most significant legislative innovation in regard to medical misadventure was probably the Accident Rehabilitation and Compensation Insurance Act 1992 (the 1992 Act) which replaced the Accident Compensation Act $1982^{28}$ and which, in section 5 , set out an extensive definition of medical misadventure. ${ }^{29}$ The change was brought about after a series of High Court decisions which had not helped to clarify the

25 Between 1881 and 1972 (when the Accident Compensation Act 1972 was passed by Parliament) there are only seven reported decisions in regard to medical malpractice in New Zealand. The most famous one of those is Smith v Auckland Hospital Board [1965] NZLR 19 (CA) concerning the concept of informed consent. The real reason for the establishment of the accident compensation scheme was the short comings identified in the Woodhouse Report: New Zealand Royal Commission of Inquiry into Compensation for Personal Injury Compensation for Personal Injury in New Zealand: Report of the Royal Commission of Inquiry (Government Printer, Wellington, 1967).

26 See for example: Cane, above n 16; Prichard, above n 16; Leo Weyers "Empfiehlt es ich im Interesse der Patienten und Aerzte ergaenzende Regelungen fuer das aerztliche Vertrags - (Standes) - und Haftungsrecht einzufuehren? Gutachten A, 52. Deutscher Juristentag Bd I (Beck, Muenchen, 1978) A 1, A 78.

27 Accident Compensation Act 1972, s 2.

28 Accident Compensation Act 1982, s 2 was, in regard to medical misadventure, identical with the Accident Compensation Act 1972, s 2 .

29 Definition of 'medical misadventure'

(1) For the purpose of this Act,-

'medical error' means the failure of a registered health professional to observe a standard of care and skill reasonably to be expected in the circumstances. It is not medical error solely because desired results are not achieved or because subsequent events show that different decisions might have produced better results:

' medical misadventure' means personal injury resulting from medical error or medical mishap:

'medical mishap' means an adverse consequence of treatment by a registered health professional, properly given if-

(a) The likelihood of the adverse consequence of the treatment occurring is rare; and

(b) The adverse consequence of the treatment is severe.

The name of the Act changed to Accident Rehabilitation and Compensation Insurance Act 1992. 
scope of the accident compensation scheme in regard to medical misadventure. ${ }^{30}$ The new medical misadventure definition narrowed the cover for medical misadventure so that, more or less, only cases of medical negligence were covered. It did this by defining medical misadventure as medical error which in turn meant "the failure of a registered health professional to observe a standard of care and skill reasonably expected in the circumstances". ${ }^{31}$ Therefore, to get cover under the 1992 Act an inquiry needed to be done to establish whether the health professional had acted negligently. And even though the health professional was not liable in tort and, therefore, their insurance and assets were "safe", blame still needed to be attributed, fault still had to be established; an oddity in a scheme essentially based on the principle of no-fault cover. Section 5 of the 1992 Act achieved legal certainty in regard to the meaning of medical misadventure. The 1992 Act was replaced by the Accident Insurance Act $1998^{32}$ and then the Injury Prevention, Rehabilitation, and Compensation Act 2001 (the 2001 Act). ${ }^{33}$ In regard to cover under the Acts for medical misadventure the key concepts were carried over. The 2001 Act filled an important oversight ${ }^{34}$ by not only including registered health professionals in the realm of the Act but also acts and omissions of organisations, especially hospitals.

Despite the introduction of tort law standards through the back door, an interesting parallel development took place, namely that patients sought recourse in punitive damages claims. ${ }^{35}$ Punitive damages are available even if the patient is covered under the accident compensation scheme since the underlying rational of punitive damages is to punish rather than to compensate. ${ }^{36}$

Furthermore, the criminal law was invoked against a doctor who made a mistake leading to serious injury or death. ${ }^{37}$ According to section 155 of the Crimes Act 1961 the criminal negligence

30 See for an overview of the case law: Petra Butler Medical Misadventure im Neuseelaendischen Accident Compensation Scheme (Peter Lang, Frankfurt, 1999) 84-92, Bruce Corkill "Medical Misadventure: Development of the Statutory Concept, and its Place in the Current Medico-Legal Environment" (February 2002) 7-16 available at $<$ http://www.acc.co.nz $>$ (last accessed 26 November 2004).

31 Accident Rehabilitation and Compensation Insurance Act 1992, s 5(1). Whether a doctor had acted negligently was assessed according to the test developed in the English courts (Sidaway v Bethlehem Royal Hospital [1985] AC 851 (HL) with a modification in Bolitho v City and Hackney Health Authority [1998] AC 232 (HL)).

32 Accident Insurance Act 1998, ss 35-37, 39, 357.

33 Injury Prevention, Rehabilitation, and Compensation Act 2001, ss 32-34.

34 See Butler, above n 30, 117.

35 Butler, above n 30, 141; Corkill, above n 30, 28.

36 Green v Matheson [1989] 3 NZLR, 564, 571 (CA) Cooke P; a more recent example is Bottrill v A [2001] 3 NZLR 622 (CA).

$37 R v$ Yogasakaran [1990] 1 NZLR 399 (CA); $R v$ McDonald (24 October 1982) HC CHCH T 24/82 Roper J; $R v$ Morrison (23 April 1994) HC DUN S 7/91 Fraser J. 
standard in regard to professional conduct was the same as the "old" negligence standard in tort. That meant that a doctor who failed to observe the professional standard normally expected in the case before him or her was criminally liable if the patient suffered any adverse physical effect from his or her treatment. Parliament has since acted to amend the Crimes Act 1961 and bring this development to a near halt. Health professionals now have to have acted in a "major departure from the standard of care expected of a reasonable person." ${ }^{138}$

In addition, the aim of the Health and Disability Commissioner Act 1994, which was initiated by the Report of the Committee of Inquiry into Allegations Concerning the Treatment of Cervical Cancer at National Women's Hospital and into Other Related Matters (the Cartwright Report), ${ }^{39}$ has been the protection and furthering of patients' rights. The Commissioner can investigate and mediate complaints in regard to the breach of the Health and Disability Services Consumer Rights and the Code of Health. Furthermore, the Commissioner has the ability to refer a case to the Director of Proceedings, either for disciplinary proceedings before the relevant professional body, or for a compensatory claim before the Complaints Review Tribunal. ${ }^{40}$ There have not been many cases referred to the Director of Proceedings. ${ }^{41}$ However, the Health and Disability Commissioners have been active in voicing concerns and opinions in health related matters and have issued opinions in regard to complaints brought before them. ${ }^{42}$

The disciplinary trials against doctors in the first 15 years of the accident compensation scheme quadrupled. ${ }^{43}$ There was also a significant increase in medical disciplinary proceedings between 1992 and 1996, as Corkill suggests ${ }^{44}$ probably due to section 5(10) of the Accident Rehabilitation and Compensation Insurance Act 1992 that gave the Accident Compensation Corporation power to notify the Medical Disciplinary Tribunal of any doctor who acted negligently or inappropriately. In

38 Crimes Act 1961, s 150A.

39 Committee of Inquiry into Allegations Concerning the Treatment of Cervical Cancer at National Women's Hospital and into Other Related Matters Report of the Committee of Inquiry into Allegations Concerning the Treatment of Cervical Cancer at National Women's Hospital and into Other Related Matters (Government Printer, Wellington, 1988) ch 7 ["Cartwright Report"] which identified that the disciplinary redress for patients against a doctor was inadequate; see in regard to the impact of the Cartwright Report on the establishment of the office of the Health and Disability Commissioner: Health Commissioner Bill 1990.

40 Health and Disability Commissioner Act 1994, s 49.

41 See for example, Director of Proceedings $v$ O'Neill [2001] NZAR 59 (HC).

42 See for an overview of publications by the Health and Disability Commissioner and opinions $<$ http://www.hdc.org.nz $>$ (last accessed 31 October 2004).

43 Jarrod Walker "The Medical Practitioners' Bill 1995" [1995] Auck U LR 1078, 1080 n 17; David Collins Medical Law in New Zealand (Brookers, Wellington, 1992) 219 and sch 7.

44 Corkill, above n 30, para 80. 
the last five years, except for 2001, the number of disciplinary proceedings was around 17 a year. ${ }^{45}$ Even though that does not seem to be an enormous number of disciplinary proceedings it seems that the public is far more aware of disciplinary proceedings against doctors than 10 years ago.

The recourse to the criminal law, the Health and Disability Commissioner Act 1994, the increase of punitive damages claims against health professionals, and the disciplinary hearings show the desire of society "to punish" health care professionals for misconduct. Patients argue that they would like to ensure that what happened to them cannot ever happen again to someone else. Patients also want quality assurance through punitive measures which involve an attribution of fault. ${ }^{46}$ Not only have patients tried to hold the medical profession accountable by using all the means available; also various governments have responded by holding the medical profession accountable by launching inquiries into medical misconduct. The Cartwright inquiry has been already mentioned, ${ }^{47}$ other examples include the Gisborne inquiry into the misreading of cervical smears by a pathologist and the inquiry into Canterbury Health Limited in regard to concerns about a high number of patient deaths. $^{48}$

Peter Roberts, quoting C Paul, argues in his paper that in "New Zealand's context, ... an environment that enhances professional virtues and internal morality holds more promise than complaint-based external morality." ${ }^{49}$ Therefore, according to his view quality is best achieved through incentives and a caring, blame-free environment. Interestingly, Bronwyn Howell's paper ${ }^{50}$ suggests nearly the opposite - that a "blame culture" as embodied in the possibility of tort law claims creates incentives for ensuring a better standard. ${ }^{51}$ She points out that in New Zealand "only the most serious cases of negligence and medical misadventure will receive the retrospective analysis and information revelation afforded by ex post facto disciplinary action." 52 What a "blame culture" might lead to has been pointed out by Frizelle who, in regard to informed consent, stated that doctors can avoid problems "if she/he works less, talks more, and writes it all down". ${ }^{53}$

45 Medical Practitioners Disciplinary Tribunal <http://www.mpdt.org.nz > (last accessed 30 October 2004).

46 See Howell, above n 24, 19.

47 Cartwright Report, above n 39.

The inquiries are instituted either by the Minister of Health or the Director of Health. See for further examples: Corkill, above n 30, 34-36.

49 Roberts, above n 2.

50 Howell, above $\mathrm{n} 24$.

51 Howell, above n 24.

52 Howell, above $\mathrm{n} 24$.

53 F Frizelle "Informed Consent: Do Less, Talk More and Write it all Down" (2002) 1162 NZ Med J 115. 
The different approaches advocated by Roberts and Howell illustrate two very important points: first, that the accident compensation scheme in regard to medical misadventure is not without problems since the doctor-patient relationship is a very special one which is based on immense trust. Once the trust is broken it causes harm - the patient feels they have not been treated with the concern that they deserve. That the doctor who always has done their best but has now slipped once in their life does not count neither does their previous performance. Secondly, as Atiyah pointed out, the solution proposed depends entirely on the philosophical attitude of the author. ${ }^{54}$ But what about the patient? What would be desirable from the patient's point of view? Is there a solution which would allow for good old-fashioned common law compensation for the clear cut negligent conduct of a doctor and still a no-fault compensation type of accident compensation scheme. The Canadian Prichard Report suggested that a patient should have choice between a non-fault compensation scheme and a tort law claim. Once the patient has elected one there was not to be any recourse through the other. ${ }^{55}$ The advantage of a split system would be that real medical misadventure could still be fully compensated and in cases of clear cut negligent conduct the patient gets his or her day in court. In cases where negligent conduct cannot easily be established patients will probably opt for the compensation scheme rather than embark on an uncertain tour through the court system. This system would give the courts the chance to review standards. For doctors, a split system would have the advantage that establishing a trusting relationship with the patient which is based on information and openness will most likely not end up in court if the doctor makes a mistake since the patient will not suffer any financial loss from the mistake. Court cases will, however, give the doctors some guidelines of what society finds acceptable practice/behaviour and what not. The British General Medical Council (GMC), for example, has asked the courts to give some guidance on its guidelines on "Withholding and Withdrawing Life-prolonging Treatment". Since the high profile High Court decision in $R$ (on the application of Burke) $v$ General Medical Council ${ }^{56}$ the GMC felt that "the case raises important points of principle, and there are some areas where we consider further clarification may be needed" and the GMC sought leave to appeal which was granted. 57

The new Injury Prevention, Rehabilitation, and Compensation Amendment Bill (No 3) 2004 gets rid of the "medical error" concept to move "away from the punitive system of finding medical error" with the aim of gaining "co-operation of the health sector to participate in the claims process, to support claimants to make claims and to provide necessary medical reports and advice to ACC

54 Cane, above n 16

55 Robert Prichard Liability and Compensation in Health Care (Department of Health, Toronto, 1990); Butler, above n 30, 164-166.

$56 R$ (on the application of Burke) $v$ General Medical Council [2004] All ER 588 (HC) Munby J.

$57<$ http://www.gmcpressoffice.org.uk> (last accessed 3 November 2004). 
promptly." 58 Peter Roberts' arguments have been heard. However, if Howell is right we will probably see another surge in the use of the other quality assurance instruments outlined above to hold the medical profession accountable. According to Howell this is the more expensive solution to accountability.

58 Injury Prevention, Rehabilitation, and Compensation Amendment Bill (No 3) 2004. 